Vol.2, No. 2, Mei. 2019

\title{
PENGARUH PENYALURAN KREDIT USAHA RAKYAT (KUR), TINGKAT SUKU BUNGA TERHADAP KINERJA KEUANGAN BANK PEMBANGUNAN DAERAH MELALUI NON PERFORMING LOAN (NPL) \& BIAYA OPERASI DAN PENDAPATAN OPERASI (BOPO) (STUDI KASUS BPD DKI JAKARTA, BPD DI YOGYAKARTA DAN BPD JAWA TIMUR)
}

\author{
Ratih Setyo Rini ${ }^{1)}$, Eko Aristanto ${ }^{2)}$ \\ 1) Universitas Bina Sarana Informatika Jakarta \\ ${ }^{2)}$ Universitas Merdeka Malang \\ Email :ratih.rsi@bsi.ac.id ${ }^{l}$
}

\begin{abstract}
Kredit Usaha Rakyat (KUR) is a credit/financing scheme specifically for micro, small and medium enterprises whose busines are feasible but do not have sufficient collateral required by the bank. This research objective was to analyze the effect of Kredit Usaha Rakyat Distribution, interest rates on financial performace of Bank Pembangunan Daerah through non-performing loans (NPL) and operating cost operating revenues (BOPO) and analyze the differences in financial performance of Bank Pembangunan Daerah before and after becoming KUR distribution bank. The sampel used in this study is the Bank Pembangunan Daerah, which has been incorporated in the KUR distribution bank in 2008, namely BPD DI Yogyakarta, BPD DKI Jakarta dan BPD Jawa Timur. The observation used data from the Bank Pembangunan Daerah for the period 2005 2015. The results of the credit distribution and interest rates in the KUR distribution did not have a significant impact on the NPL and BOPO and showed that there no better significant differences in financial performance variables in the years BPD became the KUR distributor. The result recommrnds BPD to continue distributing KUR.
\end{abstract}

Keywords : Kredit Usaha Rakyat Distribution, Interest Rate, Financial Performance

\begin{abstract}
Abstrak
Kredit Usaha Rakyat (KUR) merupakan skema Kredit/Pembiayaan yang khusus diperuntukkan bagi Usaha Mikro, Kecil dan Menengah dan Koperasi yang usahanya layak (feasible) namun tidak mempunyai agunan yang cukup sesuai persyaratan yang ditetapkan perbankan (unbankable). Tujuan penelitian menganalisis Pengaruh Penyaluran Kredit Usaha Rakyat (KUR), Tingkat Suku Bunga Terhadap Kinerja Keuangan Bank Pembangunan Daerah Melalui Non
\end{abstract}


Performing Loan (NPL) dan Biaya Operasi dan Pendapatan Operasi (BOPO) dan menganalisis perbedaaan kinerja keuangan Bank Pembangunan Daerah sebelum dan sesudah menjadi Bank Penyalur KUR. Sampel yang digunakan dalam penelitian ini yaitu Bank Pembangunan Daerah di Pulau Jawa, yang telah tergabung dalam Bank Penyalur KUR tahun 2008 yaitu BPD DI Yogyakarta, BPD Jawa Timur dan BPD DKI Jakarta. Adapun periode pengamatan mengunakan data Bank Pembangunan Daerah periode 2005-2015. Hasil penelitian penyaluran kredit dan suku bunga dalam penyaluran KUR secara umum tidak memberikan dampak bermakna terhadap NPL dan BOPO dan menunjukkan tidak ada perbedaan signifikan yang lebih baik pada variabel kinerja keuangan di tahun-tahun BPD menjadi penyalur KUR, maka memberikan saran BPD melanjutkan untuk menjadi penyalur KUR.

Kata Kunci : Kredit Usaha Rakyat, Kinerja Keuangan, Bank Pembangunan Daerah

\section{PENDAHULUAN}

\subsection{Latar Belakang Penelitian}

Upaya perluasan askes permodalan bagi usaha mikro, kecil dan menengah dan peningkatan inklusi keuangan difasilitasi pemerintah dalam bentuk Kredit Usaha Rakyat (KUR) dengan dasar Instruksi Presiden No. 6 Tahun 2007 tentang Kebijakan Percepatan Pengembangan Sektor Riil dan Pemberdayaan Usaha Mikro, Kecil dan Menengah (Eko Aristanto, 2019). Kredit Usaha Rakyat (KUR) merupakan skema Kredit/Pembiayaan bersubsidi bagi usaha mikro, kecil dan menengah yang usahanya layak (feasible), namun ketiadaan agunan yang sesuai persyaratan perbankan (unbankable). Pada awal pelaksanaan Program Kredit Usaha Rakyat (KUR) sesuai Nota Kesepahaman Bersama (MoU) tanggal 9 Oktober 2007 menjelaskan bank pelaksana KUR adalah Bank BUMN yakni sebanyak 6 Bank (Bank Mandiri, Bank BRI, Bank BNI ,Bank BTN, Bank Bukopin, dan Bank Syariah Mandiri). Sampai dengan tahun 2018 menunjukan jumlah lembaga penyalur KUR terdiri 41 lembaga (14 Bank Umum, 20 Bank Pemerintah Daerah, 5 Lembaga Keuangan Non Bank, 2 Koperasi Simpan Pinjam) peningkatan yang signifikan dibandingkan tahun 2007.

Keterlibatan Bank Pemerintah Daerah dalam pelaksanaan penyaluran Kredit Usaha Rakyat, tidak terlepas dari fungsi utama sebagai penghimpun dan penyalur dana masyarakat dengan tugas pokok pengembangan perekonomian daerah dan mengerakkan pembangunan daerah. Disamping itu, Bank Pembangunan Daerah memiliki tugas pokok tambahan dijelaskan pada pasal 3 dalam Keputusan Menteri Dalam Negeri No 62 Tahun 199 tentang Pedoman Organisasi dan Tata Kerja Bank Pembangunan Daerah yakni : (a) pendorong terciptanya tingkat pertumbuhan perekonomian dan Pembangunan Daerah dalam rangka peningkatan taraf hidup rakyat; (b) Pemegang Kas Daerah dan atau menyimpan uang daerah; dan (c) salah satu sumber Pendapatan Asli Daerah. Dengan memperhatikan tugas 
pokoknya, menunjukkan Bank Pemerintah Daerah memilkiki posisi strategis dalam mendorong kegiatan ekonomi dalam rangka pembangunan daerah (Sunarsip, 2011). Selain itu, Bank Pemerintah Daerah dikatakan memiliki keunggulan komparatif dilihat dari aspek lokasi, sehinggan lebih memahami dan menguasai peta bisnis di wilayah operasionalnya. Dengan keunggulan komparatif tersebut diharapkan, mampu menggerakkan perekonomian daerah melalui penyaluran kredit ke sektor-sektor ekonomi yang produktif.

Potensi Usaha Mikro, Kecil dan Menengah di Pulau Jawa, dengan jumlah signifikan menjadi peluang pasar bagi penyaluran KUR bagi Bank Pembangunan Daerah. Namun potensi pasar usaha mikro, kecil dan menengah tersebut diimbangi dengan potensi tingginya risiko yang dihadapi Bank Pemerintah Daerah dalam penyaluran Kredit Usaha Rakyat yakni kredit bermasalah. Kredit bermasalah dimaknai kredit yang tidak mampu diselesaikan oleh debitur terhadap kreditur sesuai dengan perjanjian kredit yang telah disepakati bersama (I Putu Mulyadi Saputra, Anjuman Zukhri, \& Luh Indrayani, 2014). Risiko kredit bermasalah pada pelaku Usaha Mikro, Kecil dan Menengah di Indonesia, tidak terlepas dari kompleksitas permasalahan yang dihadapinya dan menjelma menyerupai lingkaran setan yang tiada berujung pangkal dalam mengatasi kesulitan Usaha Mikro, Kecil dan Menengah (Firdaus \& Dewayanti, 2004). Berbagai kendala-kendala tersebut juga terdeteksi dari beberapa hasil berbagai kajian menunjukkan bahwa pengusaha mikro dan kecil selalu menghadapi kendala, antara lain : i). rendahnya kemampuan memperoleh peluang pasar dan mendapat bagian dari pasar; ii). struktur permodalan yang masih lemah dan cenderung fluktuasi; iii). pengelolaan organisasi dan manajemen usaha yang masih tradisional; iv). Ketertinggalan dalam pemanfaatan teknologi; v). keterbatasan dalam memperoleh informasi untuk melakukan jangkauan usaha dan atau kerjasama usaha. Kebijakan penanganan kredit macet pada Kredit Usaha Rakyat tertuang dalam PMK Nomor 20 /PMK.05/2016 Tentang Tata Cara Pelaksanaan Subsidi Bunga Untuk Kredit Usaha Rakyat. Risiko kredit macet atau Non Performing Loan (NPL) pada bank-bank pelaksana diatasi sendiri oleh bank pelaksana bekerjasama dengan lembaga penjaminan. Berbeda dengan KUR pola penjaminan, dimana lembaga penjamin ditunjuk oleh pemerintah, pada KUR pola subsidi bunga, lembaga penjamin ditunjuk oleh bank pelaksana. Intervensi pemerintah tidak dalam bentuk PMN dan OJP (sebagaimana pada KUR pola penjaminan), melainkan dalam bentuk subsidi bunga (belanja pemerintah) yang dialokasikan dalam APBN setiap tahun. Pemberian bunga yang rendah di satu sisi diharapkan dapat menggerakkan sektor riil.

Bank Pembangunan Daerah sebagai entitas usaha yang sarat dengan risiko, karena sumber dana dari pihak ketiga yang dikelola dalam berbagai bentuk investasi, seperti pemberian kredit, pembelian surat-surat berharga dan penanaman dana lainnya (Imam Ghozali, 2007). Dalam penyaluran KUR sumber dana yang digunakan 100\% (seratus persen) bersumber dari dana Bank Pelaksana, maka perbankan dituntut prudent dalam proses penyalurannya. Pengelolaan dana yang prudent dan baik akan menghasilkan kinerja yang baik dan efisien, yang dinilai dengan pendekatan analisis rasio keuangan terdiri Capital Adequacy Ratio (CAR) untuk permodalan, Non Performing Loans (NPL) untuk kualitas asset, Net 
Profit Margin (NPM) untuk kinerja manajemen, Return on Assets (ROA) dan Beban Operasional Pendapatan Operasional (BOPO) untuk rentabilitas, serta Loan to Deposit Ratio (LDR) untuk likuiditas. Dengan latar belakang di atas, penelitian ini menganalisis tentang pengaruh penyaluran Kredit Usaha Rakyat (KUR), tingkat suku bunga terhadap kinerja keuangan Bank Pembangunan Daerah melalui Non Performing Loan (NPL) dan Biaya Operasi Pendapatan Operasi (BOPO) dan perbedaaan kinerja keuangan Bank Pembangunan Daerah sebelum dan sesudah menjadi Bank Penyalur KUR. Dengan mengetahui bagaimana risiko dan keuntungan penyaluran KUR bagi Bank Pembangunan Daerah, dapat menjadi dasar pertimbangan bagi Bank Pembangunan Daerah sebagai Bank Penyalur KUR.

\subsection{Perumusan Masalah}

Adapun perumusan masalah penelitian, sebagai berikut :

1. Bagaimana Pengaruh Penyaluran Kredit Usaha Rakyat (KUR), Tingkat Suku Bunga terhadap Non Performing Loan (NPL) dan Biaya Operasi dan Pendapatan Operasi (BOPO).

2. Bagaimana Pengaruh Non Performing Loan (NPL) dan Biaya Operasi dan Pendapatan Operasi (BOPO) terhadap Kinerja Keuangan Bank Pembangunan Daerah

3. Bagaimana perbedaaan kinerja keuangan Bank Pembangunan Daerah sebelum dan sesudah menjadi Bank Penyalur KUR.

\subsection{Tujuan Penelitian}

Adapun tujuan penelitian, sebagai berikut :

1. Menganalisis Pengaruh Penyaluran Kredit Usaha Rakyat (KUR), Tingkat Suku Bunga Terhadap Non Performing Loan (NPL) dan Biaya Operasi dan Pendapatan Operasi (BOPO).

2. Menganalisis Pengaruh Non Performing Loan (NPL) dan Biaya Operasi dan Pendapatan Operasi (BOPO) terhadap Kinerja Keuangan Bank Pembangunan Daerah

3. Menganalisis perbedaaan kinerja keuangan Bank Pembangunan Daerah sebelum dan sesudah menjadi Bank Penyalur KUR.

\subsection{Konstribusi Penelitian}

Adapun kontribusi penelitian, sebagai berikut :

1. Bagi Peneliti

Untuk memperoleh penjelasan tentang bagaimana pengaruh Pengaruh Penyaluran Kredit Usaha Rakyat (KUR), Tingkat Suku Bunga Terhadap Kinerja Keuangan Bank Pembangunan Daerah Melalui Non Performing Loan (NPL) dan Biaya Operasi dan Pendapatan Operasi (BOPO) dan perbedaaan kinerja keuangan Bank Pembangunan Daerah sebelum dan sesudah menjadi Bank Penyalur KUR.

2. Bagi Bank Pemerintah Daerah

Memberikan cara pandang dan masukan bagi Bank Pemerintah Daerah tentang pengaruh penyaluran KUR terhadap kinerja secara keseluruhan dan 
keputusan pertimbangan keberlanjutan partisipasi Bank Pemerintah Daerah dalam penyaluran KUR.

3. Bagi Peneliti Lain

Bahan tambahan dan benchmark kepustakaan penelitian yang berkaitan dengan bidang keuangan khususnya pengaruh penyaluran KUR bagi kinerja Bank Pembangunan Daerah.

\section{KERANGKA TEORITIS DAN PENGEMBANGAN HIPOTESIS}

\subsection{Program Kredit Usaha Rakyat}

Kredit program tersebut dikenal dengan Program Kredit Usaha Rakyat atau lazim dikenal dengan istilah "KUR". Kredit Usaha Rakyat merupakan skema Kredit/Pembiayaan bersubsidi bagi Usaha Mikro, Kecil dan Menengah dan Koperasi dengan usaha layak (feasible) dan tidak mempunyai agunan persyaratan yang ditetapkan perbankan (unbankable). Di samping itu dari sisi bisnis, usaha yang akan dibiayai memiliki prospek bisnis yang baik dan mampu mengembalikan kredit. Dalam pelaksanaan Program Kredit Usaha Rakyat (KUR), terdapat 3 (tiga) pilar penting dalam rangka pencapaian tujuannya yaitu : i) Pemerintah dengan fungsi membantu dan mendukung pelaksanaan pemberian kredit berikut penjaminan kredit, ii) Lembaga Penjaminan berfungsi sebagai penjamin atas kredit/pembiayaan yang disalurkan oleh Perbankan, dan iii) Perbankan berfungsi penyalur kredit kepada UMKM \& Koperasi. Berdasarkan Landasan hukum Kredit Usaha Rakyat (KUR), skema program Kredit Usaha Rakyat (KUR) dengan penjaminan pemerintah memiliki perbedaan dengan skema kredit program lain yang dikeluarkan oleh pemerintah.

Berikut uraian ringkas beberapa ketentuan utama Skema, Plafon Pinjaman dan Suku Bunga Kredit Usaha Rakyat (KUR) sebagaimana telah ditentukan, antara lain:

Tabel 2.1

Skema, Plafon Pinjaman dan Suku Bunga Kredit Usaha Rakyat (KUR)

\begin{tabular}{|c|c|c|c|}
\hline \multirow{2}{*}{ Keterangan } & \multicolumn{3}{|c|}{ Kredit Usaha Rakyat (KUR) } \\
\hline & 2007 & 2012 & 2018 \\
\hline Skema & Penjaminan Kredit & Penjaminan Kredit & Subsidi Bunga \\
\hline $\begin{array}{l}\text { Plafon } \\
\text { Pinjaman } \\
\text { - KUR Mikro } \\
\text { - KUR Ritel } \\
\text { - KUR TKI } \\
\text { - KUR } \\
\text { Khusus } \\
\end{array}$ & $\begin{array}{l}\text { - Rp } 1 \text { Juta-Rp. } 5 \\
\text { Juta } \\
\text { - Rp } 5 \text { Juta - Rp. } \\
\text { 500 Juta }\end{array}$ & $\begin{array}{l}\text { - Rp } 5 \text { Juta - Rp. } \\
20 \text { Juta } \\
\text { - Rp } 20 \text { Juta - Rp. } \\
500 \text { Juta }\end{array}$ & $\begin{array}{l}\text { - Maks Rp. } 25 \text { Juta } \\
\text { - Diatas Rp. } 25 \text { Juta - } \\
\text { Rp. } 500 \text { Juta } \\
\text { - Maks Rp. } 25 \text { Juta } \\
\text { - Diatas Rp. } 25 \text { Juta - } \\
\text { Rp. } 500 \text { Juta }\end{array}$ \\
\hline $\begin{array}{l}\text { Suku Bunga } \\
\text { - } \text { KUR Mikro } \\
\text { - } \text { KUR Ritel }\end{array}$ & $\begin{array}{l}\text { - } 24 \% \text { p.a } \\
\text { - } 16 \% \text { p.a }\end{array}$ & $\begin{array}{l}\text { - } 22 \% \text { p.a } \\
\text { - } 14 \% \text { p.a }\end{array}$ & $\begin{array}{l}\text { - } 7 \% \text { efektif pertahun } \\
\text { (Subsidi Bunga 10,5 } \\
\% \text { ) }\end{array}$ \\
\hline
\end{tabular}




\begin{tabular}{lc}
\hline - KUR TKI & - $7 \%$ efektif pertahun \\
& (Subsidi Bunga 5,5\%) \\
- KUR & $-7 \%$ efektif pertahun \\
Khusus & (Subsidi Bunga 14 \%) \\
& $-7 \%$ efektif pertahun \\
(Subsidi Bunga 5,5\%) \\
\hline
\end{tabular}

Sumber : Data Sekunder (diolah), 2018

\subsection{Tingkat Suku Bunga Subsidi}

Dalam operasional perbankan, penyaluran dana dalam bentuk kredit merupakan produk utama. Penyaluran kredit perbankan kepada para debitur memberikan pendapatan bunga. Pengertian tingkat bunga menurut Sawaldjo Puspopranoto (2004) adalah biaya peminjaman atau harga yang dibayar untuk meminjam sejumlah dana. Lebih lanjut menurut Puspopranoto S (2004), metode penentuan tingkat bunga secara umum dikemukakan oleh Cargill, TF (1991: 9099) dengan dua pendekatan, yaitu Liquidity Preference menjelaskankan suku bunga merupakan kesimbangan antara jumlah uang yang diminta dan ditawarkan pada sistem keuangan (Puspopranoto S, 2004) dan Loanable Funds menjelasan suku bunga merupakan bagian sistem keuangan yang menjaga keseimbangan dana dipinjamkan dan diperdagangkan di pasar primer dan sekunder dan tingkat bunga menyamakan penawaran dan permintaan akan dana yang dapat dipinjamkan.

Program KUR hakikatnya adalah pemberian subsidi dari pemerintah kepada bank-bank tertentu yang ditunjuk (sebagian besar bank pemerintah) sehingga dapat memberikan bunga kredit lebih murah. Dengan adanya kemudahan kredit untuk Usaha Mikro, Kecil, dan Menengah (UMKM) yang diikuti dengan penurunan suku bunga diharapkan dapat mendongrak kinerja perekonomian nasional (Meby Damayanti \& Latief Adam, 2015). Dalam konteks Kredit Usaha Rakyat bahwa suku bunga yang rendah dengan bantuan subsidi bunga dari pemerintah adalah bentuk subsidi, sehingga suku bunganya menjadi lebih rendah suku bunga di pasar umum. Pemberian subsidi dari pemerintah kepada bank-bank tertentu yang ditunjuk sehingga bank-bank yang ditunjuk dapat memberikan bunga kredit lebih murah tanpa mengurangi tingkat keuntungan bank. Sebagaimana pada umumnya, atas penyaluran KUR, bank pelaksana mengenakan bunga pada debitur KUR. Untuk KUR Retail dikenakan bunga efektif maksimal sebesar 13\%, sedangkan KUR Mikro dikenakan bunga maksimal 22\% per tahun. Bila dibandingkan dengan suku bunga dasar kredit (SBDK) retail sesuai dengan SE Bank Indonesia No. 13/5/DPNP merupakan tingkat suku bunga terendah yang menjadi dasar bagi Bank dalam menentukan tingkat suku bunga kredit yang dikenakan kepada nasabah Bank.

\subsection{Rasio Kredit Bermasalah dan Non Performing Loan (NPL)}

Perbankan adalah entitas binsis yang rentan dan berisiko, khususnya risiko dalam pengelolaan uang (money). Bank sebagai lembaga perantara keuangan yang menghimpun dana masyarakat dan penyaluran kredit dengan prinsip prudential (kehati-hatian) dalam (Retnadi D, 2006). Ketidakhati-hatian dalam proses penyaluran kredit akan menimbulkan kredit macet. Mengutip pernyataan Dennis Weatherstone, Retired Chairman - JP Morgan \& Co menjelaskan bahwa 
Bank is a "risk machine". it takes risks, it transforms them, it embedes them in banking products and service. in this context, those banks which actively manage their risk have decisive competitive advantage. they take risk more consciously, they anticipate adverse changes, they protect them selves from unexpected events, they gain the expertise to price risks". Berdasarkan penjelasan di atas, bank adalah "risiko mesin", dengan kondisi tersebut produk dan pelayanan perbanan yang disalurkan harus mampu meminimalisasi risiko.

Pengertian lain risiko kredit adalah risiko ketidakmampuan pengembalian pinjaman dan pokok pinjaman sesuai waktu jatuh tempo. Menurut Timothy W. Koch \& S. Scott MacDonald (2009) mendefinisikan, Non performing loan is loans are more than 90 days past due. Lebih lanjut Edward W. Reed \& Edward K. Gill (1989) menjelaskan NPL sebagai Problem loans are those that have not been off but are at least 90 days past due, non accruing, or renegotiated. Dengan merujuk beberapa beberapa pengertian non performing loan (NPL), maka kredit bermasalah sebagai suatu kondisi dimana debitur sudah tidak mampu membayar sebagian atau seluruh kewajibannya kepada kreditur sesuai yang diperjanjikan. Risiko kredit diukur mengunakan Non Performing Loan (NPL) sebagai rasio keuangan kemampuan bank dalam meminimalkan kredit bermasalah yang dihadapi (Diana Puspitasari, 2009). Adapun rasio Non Performing Loan (NPL) adalah membandingkan total kredit bermasalah dengan total kredit.

\subsection{Efisiensi Perbankan dan BOPO}

Efisien dalam pengelolaan dana perbankan sangat penting, mengingat bank berfungsi sebagai lembaga perantara keuangan. Bagi perbankan makna kata efisiensi dapat dikondisikan dengan kemampuan menghasilkan keuntungan yang dapat dimaksimalkan, sedangkan biaya operasional harus dapat dikendalikan atau diminimumkan. Efisiensi operasi bagi perbankan dapat mempengaruhi kinerja bank, yakni untuk menunjukkan bagaimana bank menggunakan semua faktor produksinya dengan tepat, guna mencapai keberhasilan yang telah diharapkan (Sholikha Oktavi Khalifaturafi'ah \& Zubaidah Nasution, 2016). Efisiensi pada perbankan diukur dengan mengunakan rasio Biaya Operasional Pendapatan Operasional (BOPO). Di mana rasio BOPO merupakan perbandingan antara total biaya operasional dengan total pendapatan operasional. Rasio BOPO yang semakin kecil, menunjukan kemampuan bank dalam meminimalisasi biaya operasional untuk mendapatkan pendapatan yang dapat membantu meningkatkan kinerja bank. Sebagai ukuran terbaik dalam pengelolaan BOPO, Bank Indonesia bahwa rasio BOPO adalah dibawah 90\%. Apabila rasio BOPO telah melebihi 90\% hingga mendekati angka 100\% maka bank tersebut tidak efisien dalam operasionalnya.

\subsection{Kinerja Perbankan}

Kehati-hatian perbankan dalam operasionalnya merupakan upaya perbankan dalam menjaga keberlangsungan kegiatannya dan sekaligus untuk terus meningkatkan kinerjanya. Kinerja perbankan yang baik berimplikasi terhadap perkembangan dunia usaha dana pertumbuhan ekonomi secara nasional. Dengan merujuk pada hal di atas, menjelaskan arti pentingnya perbankan menjaga kinerja 
keuangannya, sehingga penilaian kinerja perbankan merupakan hal yang penting. Penilaian kinerja perbankan dapat dilihat dari laporan terhadap berbagai aktivitas keuangan perbankan yang terangkum dalam Laporan Keuangan. Lebih lanjut (Dwi Prastowo, 2015) menyatakan "tujuan dari laporan keuangan yaitu untuk menyediakan infomasi yang berkaitan dengan posisi keuangan seperti keuntungan, risiko, fleksibilitas keuangan, dan kinerja operasional perusahaan yang dapat bermanfaat bagi sejumlah besar pemakai dalam pengambilan keputusan ekonomi". Pengertian di atas menjelasan betapa pentingnya laporan keuangan perbanan sebagai rujukan informasi untuk mengetahui kinerja keuangan perbankan bagi para pihak yang bersangkutan seperti investor, kreditur, dan pemerintah.

Kinerja perbankan diukur dengan pendekatan analisis rasio keuangan (Etty M. Nasser, 2003). Pada umum kinerja perbankan diukur dengan lima aspek yaitu CAMEL (Capital, Asset Quality, Management, Earnings dan Liquidity) (Sumarta dan Hartono, 2000). Kelima aspek penilaian tersebut dalam penelitian ini diproksi dengan enam rasio keuangan perbankan, yaitu Capital Adequacy Ratio (CAR) untuk permodalan, Non Performing Loans (NPL) untuk kualitas asset, Net Profit Margin (NPM) untuk manajemen, Return on Assets (ROA) dan Beban Operasional Pendapatan Operasional (BOPO) untuk rentabilitas, serta Loan to Deposit Ratio (LDR) untuk likuiditas.

\subsection{Hipotesis}

Mendasarkan pada kerangka pemikiran, hipotesis penelitian adalah sebagai berikut:

$\mathrm{Ha}_{1}$ : Pengaruh Penyaluran Kredit Usaha Rakyat (KUR), Tingkat Suku Bunga Terhadap Non Performing Loan (NPL).

$\mathrm{Ha}_{2}$ : Pengaruh Penyaluran Kredit Usaha Rakyat (KUR), Tingkat Suku Bunga Terhadap Biaya Operasi dan Pendapatan Operasi (BOPO).

$\mathrm{Ha}_{3}$ : Pengaruh Non Performing Loan (NPL) dan Biaya Operasi dan Pendapatan Operasi (BOPO) terhadap Kinerja Keuangan Bank Pembangunan Daerah

$\mathrm{Ha}_{4}$ : Terdapat Perbedaaan antara NPL, NIM, ROE dan ROA sebelum 3 tahun dan sesudah 3 tahun menjadi Bank Penyalur KUR.

$\mathrm{Ha}_{5}$ : Terdapat Perbedaaan antara NPL, NIM, ROE dan ROA sebelum 3 tahun dan sesudah 4 tahun menjadi Bank Penyalur KUR.

$\mathrm{Ha}_{6}$ : Terdapat Perbedaaan antara NPL, NIM, ROE dan ROA sebelum 3 tahun dan sesudah 5 tahun menjadi Bank Penyalur KUR.

$\mathrm{Ha}_{7}$ : Terdapat Perbedaaan antara NPL, NIM, ROE dan ROA sebelum 3 tahun dan sesudah 6 tahun menjadi Bank Penyalur KUR.

$\mathrm{Ha}_{8}$ : Terdapat Perbedaaan antara NPL, NIM, ROE dan ROA sebelum 3 tahun dan sesudah 7 tahun menjadi Bank Penyalur KUR. 
Vol.2, No. 2, Mei. 2019

\section{METODE RISET}

\subsection{Rancangan Penelitian}

Rancangan penelitian ini mengunakan penelitian verifikatif yaitu metode penelitian yang bertujuan untuk menguji hubungan dan pengaruh antar dua variabel atau lebih. Dalam penelitian ini terdapat pemasalahan utama yang harus diuji yaitu (a) Pengaruh Penyaluran Kredit Usaha Rakyat (KUR), Tingkat Suku Bunga Terhadap Kinerja Keuangan Bank Pembangunan Daerah Melalui Non Performing Loan (NPL) dan Biaya Operasi dan Pendapatan Operasi (BOPO) dan (b) menguji perbedaan kinerja keuangan Bank Pembangunan Daerah sebelum dan sesudah menjadi Bank Penyalur KUR. Data-data penelitian dikumpulkan dengan dokumentasi melalui web masing-masing Bank Pembangunan Daerah dan Otoritas Jasa Keuangan untuk mengumpulan data sekunder yang berasal dari Laporan Keuangan masing-masing Bank Pembangunanan Daerah. Adapun data sekunder yang dikumpulkan dari laporan keuangan selama periode pengamatan mulai tahun 2005 sampai dengan 2015.

\subsection{Populasi dan Sampel}

Populasi yang dipakai pada penelitian ini adalah Bank Pembangunan Daerah yang menyalurkan Kredit Usaha Rakyat (KUR) pada periode 2005-2015. Sampel yang digunakan dalam penelitian ini yaitu Bank Pembangunan Daerah di Pulau Jawa, yang telah tergabung dalam Bank Penyalur KUR sejak tahun 2008 dengan sampel data amatan 3 tahun sebelum dan 7 tahun sesudah. Adapun sampel Bank Pembangunan Daerah yang konsinsten melakukan penyaluran KUR selama periode tahun 2005 sampai dengan 2015 adalah BPD DI Yogyakarta, BPD Jawa Timur dan BPD DKI Jakarta.

\subsection{Metode Analisis Data}

Metode analisis data yang digunakan untuk menjawab permasalahan dan menguji hipotesis penelitian meliputi : (i) Statistik deskripsi digunakan untuk mendapatkan deskripsi data dengan melihat kecenderungan pola data yang sedang dianalisis; (2) Melakukan uji t sampel berpasangan dan paired sample $t$ test dengan tingkat keyakinan kebenaran pengujian sebesar 95 persen. Adapun pengujian paired sample t test menggunakan perbandingan data periode 3 tahun sebelum dan data periode 3 samapai dengan 7 tahun sesudah pada Bank Pembangunan Daerah sebagai penyaluran KUR; dan (c) Metode Analisis jalur untuk mengukur besarnya pengaruh langsung maupun tidak langsung dari variabel yang diteliti. Adapun diagram model analisis jalur dalam penelitian ini dapat digambarkan sebagai berikut 


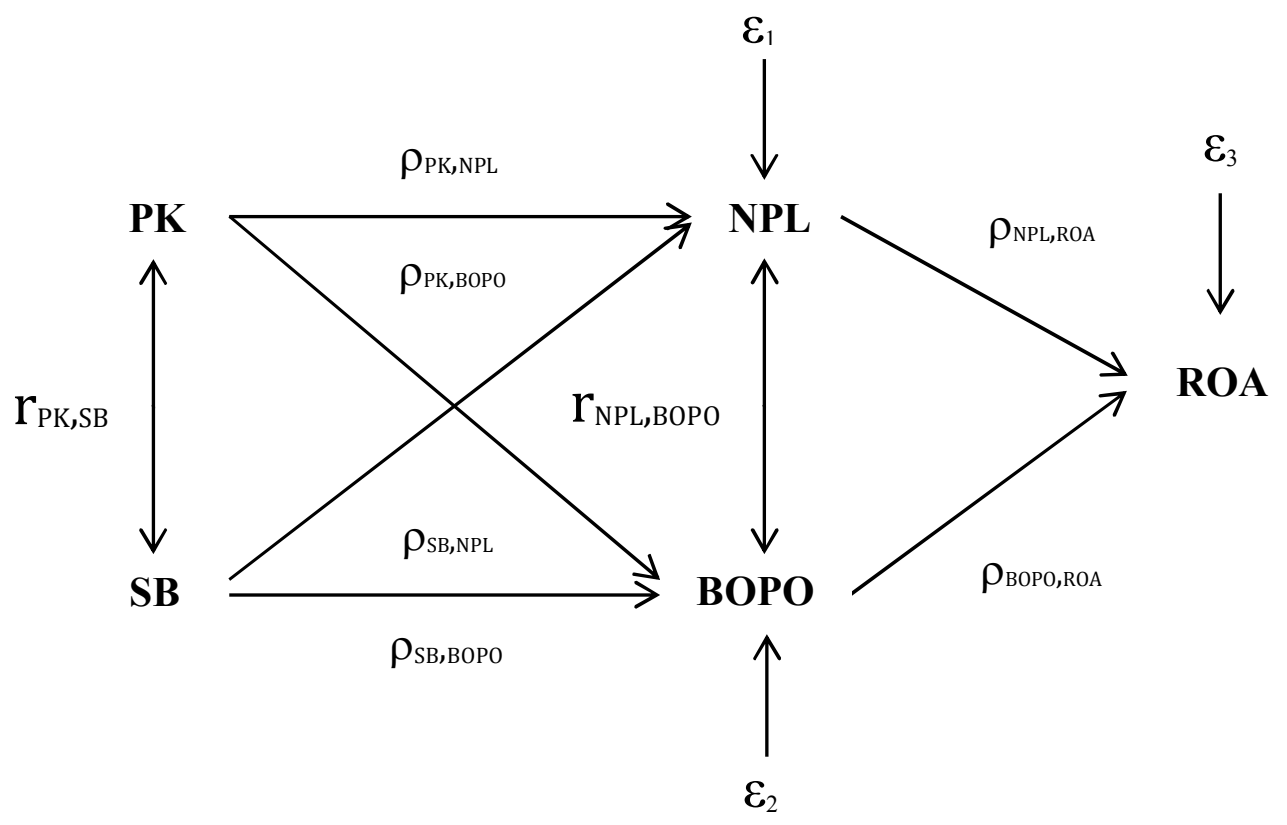

Gambar 3.1

Diagram Analisis Jalur

Keterangan :

$\begin{array}{lll}\text { PK } & : \text { Penyaluran Kredit } \\ \text { SB } & : \text { Suku Bunga Kredit } \\ \text { NPL } & : \text { Non Performing Loan } \\ \text { BOPO } & : \text { Biaya Operasional Pendapatan Operasional } \\ \text { ROA } & : \text { Return On Asset } \\ \rho_{\mathrm{PK}, \mathrm{NPL}} & : \text { Koefisien jalur Penyaluran Kredit terhadap Non Performing Loan } \\ \rho_{\mathrm{SB}, \mathrm{NPL}} & : \text { Koefisien jalur Suku Bunga Kredit terhadap Non Performing Loan } \\ & & \\ \rho_{\mathrm{PK}, \mathrm{BOPO}} & : & \text { Koefisien jalur Penyaluran Kredit terhadap BOPO } \\ \rho_{\mathrm{SB}, \mathrm{BOPO}} & : \text { Koefisien jalur Suku Bunga Kredit terhadap BOPO } \\ \rho_{\mathrm{NPL}, \mathrm{ROA}} & : \text { Koefisien jalur Non Performing Loan terhadap Return On Asset } \\ \rho_{\mathrm{BOPO}, \mathrm{ROA}} & : \text { Koefisien jalur BOPO terhadap Return On Asset } \\ \mathrm{r}_{\mathrm{PK}, \mathrm{SB}} & : \text { Koefisien korelasi antara variabel independen } \\ \varepsilon & : \text { Pengaruh faktor lain }\end{array}$


Vol.2, No. 2, Mei. 2019

\section{ANALISIS DATA DAN PEMBAHASAN}

\subsection{Analisis Data}

Sampel penelitian ini Bank Pembangunan Daerah penyalur KUR di Pulau Jawa yang meliputi BPD DI Yogyakarta, BPD Jawa Timur, BPD DKI Jakarta. Adapun variabel penelitian yang diamati adalah penyaluran KUR, tingkat suku bunga KUR, NPL, ROE, ROA dan NIM. Hasil pengolahan data, deskripsi data variabel penelitian, yaitu :

Tabel 4.1

Deskripsi Data Penelitian

\begin{tabular}{cccccc}
\hline Desciptive Statistic & $\mathbf{N}$ & Minimum & Maximum & Mean & Std. Deviation \\
\hline Kredit & 33 & 20,43 & 1.818 & 363,50 & 504,25 \\
\hline Suku Bunga & 33 & 9 & 19,20 & 15,08 & 3,01 \\
\hline NPL & 33 & 0,43 & 5,76 & 2,31 & 1,59 \\
\hline BOPO & 33 & 59,38 & 101,94 & 73,95 & 8,83 \\
\hline ROE & 33 & 1,39 & 5,48 & 3,00 & 1,00 \\
\hline ROA & 33 & 13,80 & 40,57 & 24,31 & 7,50 \\
\hline NIM & 33 & 5,26 & 12,48 & 7,82 & 1,69 \\
\hline
\end{tabular}

Sumber: Hasil Pengolahan Data Sekunder, 2018

Berdasarkan tabel statistik deskriptif di atas, Kredit nilai mean lebih kecil dari standart deviasi hal ini berarti pada variabel ini penyebaran datanya terdapat jarak yang besar antara mean setiap unit data dengan mean hitung, sehingga datanya terdapat kecenderungan yang berbeda satu sama lain. Sedangkan untuk Suku Bunga, NPL, BOPO, ROE, ROA dan NIM nilai mean lebih besar dari standart deviasi yang mana berarti datanya memiliki kecenderungan angka yang hampir sama satu sama lainnya.

Adapun rasio kinerja keuangan Bank Pembangunan Daerah tahun 20052015, yang sebagai sampel penelitian sebagai berikut :

Tabel 4.2

Rasio Kinerja BPD Tahun 2005 - 2015

\begin{tabular}{|c|c|c|c|c|c|c|c|c|c|c|c|c|}
\hline \multirow{4}{*}{ Tahun } & \multicolumn{12}{|c|}{ Bank Pembangunan Daerah } \\
\hline & \multicolumn{4}{|c|}{ BPD DI Yogyakarta } & \multicolumn{4}{|c|}{ BPD Jawa Timur } & \multicolumn{4}{|c|}{ BPD DKI } \\
\hline & NP & RO & RO & NI & NP & RO & RO & NI & NP & RO & RO & NI \\
\hline & $\mathbf{L}$ & $\mathbf{A}$ & $\mathbf{E}$ & M & $\mathbf{L}$ & $\mathbf{A}$ & $\mathbf{E}$ & M & $\mathbf{L}$ & $\mathbf{A}$ & $\mathbf{E}$ & $\mathbf{M}$ \\
\hline \multirow[t]{2}{*}{2005} & & & 27,8 & 12,4 & & & & & & & 16,9 & \\
\hline & 0,97 & 3,81 & 8 & 8 & 0,61 & 4,14 & 36,9 & 9,39 & 5,36 & 1,82 & 1 & 6,68 \\
\hline \multirow[t]{2}{*}{2006} & & & 25,7 & 10,5 & & & 38,4 & & & & & \\
\hline & 1,53 & 2,67 & 1 & 5 & 0,43 & 4,07 & 8 & 9,34 & 4,55 & 1,65 & 15,6 & 6,43 \\
\hline \multirow[t]{2}{*}{2007} & & & 25,3 & & & & 30,8 & & & & & \\
\hline & 1,12 & 2,67 & 2 & 9,24 & 0,69 & 3,55 & 5 & 7,28 & 4,15 & 1,39 & 14 & 6,99 \\
\hline \multirow[t]{2}{*}{$2008 *$} & & & & & & & 31,4 & & & & 15,0 & \\
\hline & 1,38 & 3,11 & 26,1 & 9,60 & 0,72 & 3,94 & 8 & 8,35 & 4,92 & 1,41 & 4 & 6,62 \\
\hline \multirow[t]{2}{*}{2009} & & & & & & & 28,5 & & & & & \\
\hline & 1,36 & 3,24 & 21 & 9,61 & 1,05 & 3,75 & 9 & 7,66 & 5,76 & 1,41 & 17 & 6,14 \\
\hline 2010 & 1,39 & 2,79 & 19,4 & 10,2 & 0,65 & 5,58 & 40,5 & 9,17 & 3,73 & 2,14 & 18,3 & 5,61 \\
\hline
\end{tabular}


Vol.2, No. 2, Mei. 2019

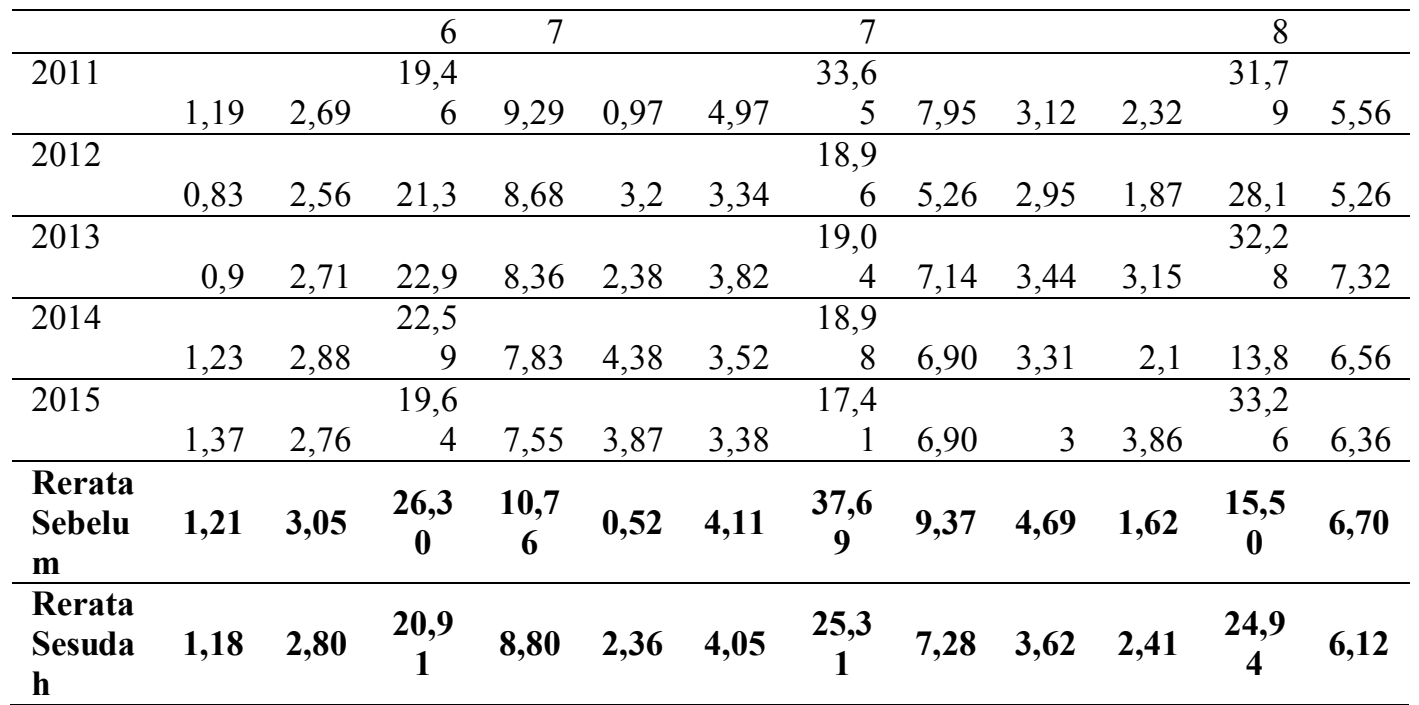

Sumber : Laporan Keuangan Tahunan BPD tahun 2005-2015

Keterangan :

*) Mulai sebagai Bank Penyalur KUR

Data kinerja keuangan pada BPD DI Yogyakarta, BPD Jawa Timur dan BPD DKI Jakarta terdiri NPL, ROA, ROE dan NIM. Nilai Rerata NPL setelah BPD DI Yogyakarta dan BPD DKI Jakarta menjadi Penyalur KUR memiliki nilai lebih rendah dibanding sebelum menjadi Bank Penyalur KUR. Kondisi tersebut, menunjukkan sebaliknya yang terjadi pada Rerata NPL setelah BPD Jawa Timur memiliki nilai lebih tinggi dibanding sebelum menjadi Bank Penyalur KUR. Namun secara umum kondisi NPL Bank Pembangunan Daerah sebagai sebagai Penyalur KUR masih berada dibawah ambang tolerasi yakni $5 \%$. Nilai Rerata ROA setelah BPD DI Yogyakarta dan BPD Jatim menjadi Penyalur KUR memiliki nilai lebih rendah dibanding sebelum menjadi Bank Penyalur KUR. Kondisi tersebut, menunjukkan sebaliknya yang terjadi pada Rerata ROA setelah BPD DKI Jakarta memiliki nilai lebih tinggi dibanding sebelum menjadi Bank Penyalur KUR. Nilai Rerata ROE setelah BPD DI Yogyakarta dan BPD Jatim menjadi Penyalur KUR memiliki nilai lebih rendah dibanding sebelum menjadi Bank Penyalur KUR. Kondisi tersebut, menunjukkan sebaliknya yang terjadi pada Rerata ROE setelah BPD DKI Jakarta memiliki nilai lebih tinggi dibanding sebelum menjadi Bank Penyalur KUR. Nilai Rerata NIM setelah BPD DI Yogyakarta, BPD DKI Jakarta dan BPD Jatim menjadi Penyalur KUR memiliki nilai lebih rendah dibanding sebelum menjadi Bank Penyalur KUR.

Adapun pengujian Analisis Jalur (Path Analysis) terhadap ketiga substruktur, sebagai berikut :

Tabel 4.3

Hasil Perhitungan Analisis Jalur (Path Analysis)

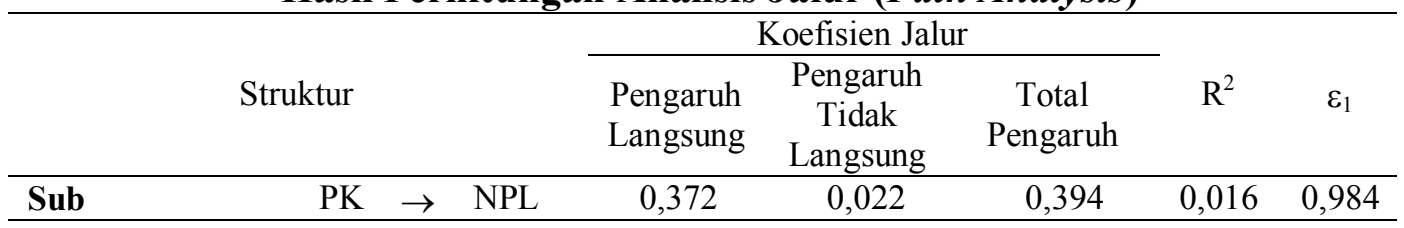


Vol.2, No. 2, Mei. 2019

\begin{tabular}{|c|c|c|c|c|c|c|c|c|}
\hline \multirow{2}{*}{$\begin{array}{l}\text { Struktur } \\
1\end{array}$} & SB & $\rightarrow$ & NPL & 0,008 & 0,022 & 0,030 & & \\
\hline & PK SB & $\rightarrow$ & NPL & & & 0,424 & & \multirow{4}{*}{0,731} \\
\hline \multirow{3}{*}{$\begin{array}{l}\text { Sub } \\
\text { Struktur } \\
2\end{array}$} & PK & $\rightarrow$ & BOPO & 0,226 & 0,017 & 0,243 & \multirow{3}{*}{0,269} & \\
\hline & SB & $\rightarrow$ & BOPO & 0,009 & 0,017 & 0,026 & & \\
\hline & PK, SB & $\rightarrow$ & BOPO & & & 0,269 & & \\
\hline \multirow{3}{*}{$\begin{array}{l}\text { Sub } \\
\text { Struktur } \\
\mathbf{3}\end{array}$} & BOPO & $\rightarrow$ & ROA & 0,345 & 0,100 & 0,445 & \multirow{3}{*}{0,682} & \multirow{3}{*}{0,318} \\
\hline & NPL & $\rightarrow$ & ROA & 0,138 & 0,100 & 0,238 & & \\
\hline & BOPO,NPL & $\rightarrow$ & ROA & & & 0,683 & & \\
\hline
\end{tabular}

Tabel 4.4

Ringkasan Estimasi Persamaan Struktural

\begin{tabular}{ccc}
\hline Model Struktural & Persamaan Struktural Estimasi & $\mathbf{R}^{2}$ \\
\hline $\mathrm{NPL}=\mathrm{b}_{1}$ Kredit $+\mathrm{b}_{1} \mathrm{SB}+\varepsilon_{1}$ & $\mathrm{NPL}=0,394$ Kredit $+0,030 \mathrm{SB}+0,984$ & 0,016 \\
\hline $\mathrm{BOPO}=\mathrm{b}_{1}$ Kredit $+\mathrm{b}_{1} \mathrm{SB}+\varepsilon_{2}$ & $\mathrm{BOPO}=0,243 \mathrm{Kredit}+0,026 \mathrm{SB}+0,731$ & 0,269 \\
\hline $\mathrm{ROA}=\mathrm{b}_{1} \mathrm{BOPO}+\mathrm{b}_{1} \mathrm{NPL}+\varepsilon_{3}$ & $\mathrm{ROA}=0,445 \mathrm{BOPO}+0,238 \mathrm{NPL}+0,318$ & 0,682 \\
\hline
\end{tabular}

Sumber: Hasil Pengolahan Data Sekunder, 2018

Berdasarkan tabel 4 dan 5, maka dapat dijelaskan sebagai berikut :

\section{Pengujian Sub Struktur 1 (PK, SB $\rightarrow$ NPL) :}

- Variabel PK yang secara langsung menentukan perubahan NPL adalah 0,372 dan melalui hubungan dengan SB sebesar 0,022 dengan demikian, secara total PK menentukan perubahan NPL sebesar 0,394.

- Variabel SB yang secara langsung menentukan perubahan NPL adalah 0,008 dan melalui hubungan dengan PK sebesar 0,022 dengan demikian, secara total SB menentukan perubahan NPL sebesar 0,030.

- Variabel PK dan SB secara bersama-sama mempengaruhi NPL sebesar 0,394 + $0,030=0,424$. Kontribusi besarnya pengaruh yang disebabkan oleh variabel lain di luar PK dan SB dijelaskan oleh $\rho_{\text {NPL } \varepsilon}^{2}$ yaitu sebesar $(0,992)^{2}=0,984$.

Pengujian Sub Struktur 2 (PK, SB $\rightarrow$ BOPO) :

- Variabel PK yang secara langsung menentukan perubahan BOPO adalah 0,226 dan melalui hubungan dengan SB sebesar 0,017 dengan demikian, secara total PK menentukan perubahan BOPO sebesar 0,243.

- Variabel SB yang secara langsung menentukan perubahan BOPO adalah 0,009 dan melalui hubungan dengan PK sebesar 0,017 dengan demikian, secara total SB menentukan perubahan BOPO sebesar 0,026.

- Variabel PK dan SB secara bersama-sama mempengaruhi BOPO sebesar 0,243 $+0,026=0,269$. Kontribusi besarnya pengaruh yang disebabkan oleh variabel lain di luar PK dan SB dijelaskan oleh $\rho_{\text {ВОРО }}^{2}$ yaitu sebesar $(0,855)^{2}=0,731$.

Pengujian Sub Struktur 3 (NPL, BOPO $\rightarrow$ ROA) :

- Variabel NPL yang secara langsung menentukan perubahan ROA adalah 0,138 dan melalui hubungan dengan BOPO sebesar 0,100 dengan demikian, secara total NPL menentukan perubahan ROA sebesar 0,238.

- Variabel BOPO yang secara langsung menentukan perubahan ROA adalah 0,345 dan melalui hubungan dengan NPL sebesar 0,100 dengan demikian, secara total BOPO menentukan perubahan ROA sebesar 0,445. 
- Variabel NPL dan BOPO secara bersama-sama mempengaruhi ROA sebesar $0,238+0,445=0,683$. Kontribusi besarnya pengaruh yang disebabkan oleh variabel lain di luar NPL dan BOPO dijelaskan oleh $\rho_{\text {ROA }}^{2}$ yaitu sebesar $(0,564)^{2}=0,318$

Adapun pengujian terhadap hipotesis yang diajukan dapat disimpulkan sebagai berikut :

- Pengujian koefisien jalur, bahwa jalur PK ke NPL dan SB ke NPL keduaduanya secara statistik adalah tidak bermakna. ( $\mathrm{t}_{\text {hitung }}=0,309$ dan $-0,462 \mathrm{di}$ bawah $\mathrm{t}_{\text {tabel }}=1,693$ dan $\rho$-value $=0,759$ dan 0,648 diatas 0,05$)$

- Pengujian koefisien jalur, bahwa jalur SB ke BOPO secara statistik adalah tidak bermakna. $\left(\mathrm{t}_{\text {hitung }}=-2,802\right.$ di bawah $\mathrm{t}_{\text {tabel }}=1,693$ dan $\rho$-value $=0,587$ diatas 0,05$)$ dan PK ke BOPO secara statistik adalah bermakna. $\left(\mathrm{t}_{\text {hitung }}=-2,802\right.$ di atas $\mathrm{t}_{\text {tabel }}=1,693$ dan $\rho$-value $=0,009$ di bawah 0,05)

- Pengujian koefisien jalur, bahwa jalur NPL ke ROA dan BOPO ke ROA kedua-duanya secara statistik adalah bermakna. ( $\mathrm{t}_{\text {hitung }}=-5,063$ dan $-3,204 \mathrm{di}$ atas $\mathrm{t}_{\text {tabel }}=1,693$ dan $\rho$-value $=0,000$ dan 0,003 di bawah 0,05 )

Adapun hasil pengujian perbedaan dengan mengunakan metode Paired Sample $t$ Test pada variabel NPL, ROA, ROE dan NIM pada sampel Bank Pemerintah Daerah sebagai Bank Penyalur KUR, sebagai berikut :

Tabel 4.5

Hasil Pengujian Paired Sampel t Test

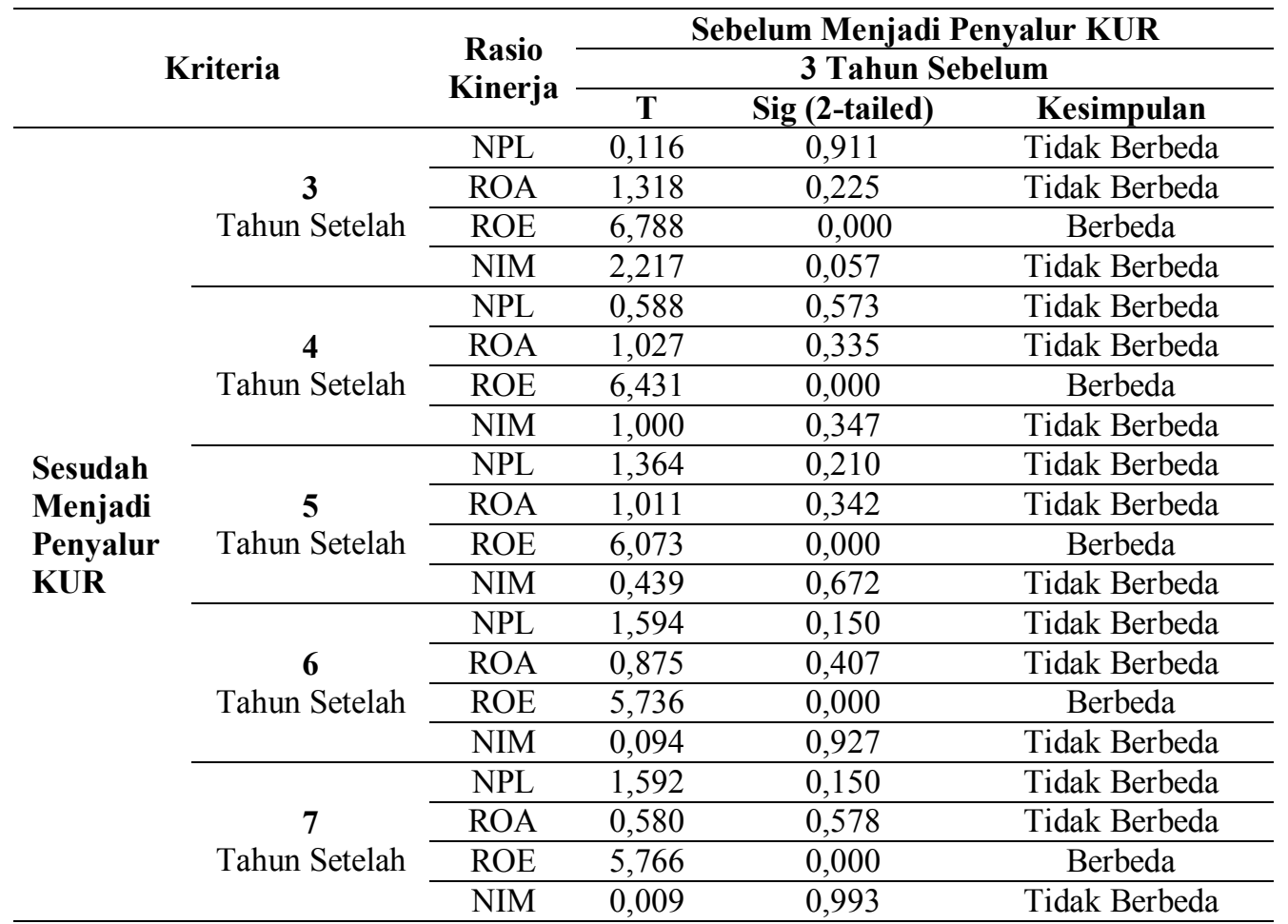

Sumber: Hasil Pengolahan Data Sekunder, 2018 
Berdasarkan tabel 6, secara keseluruhan untuk pada semua rasio yakni NPL, ROA, ROE dan NIM pada BPD DI Yogyaarta, BPD DKI Jakarta dan BPD Jawa Timur tidak berbeda singnifikan pada periode sebelum dan sesudah menjadi penyalur KUR. Dengan demikian H1, H2, H3, H4 tidak terdukung. Untuk rasio ROE pada pengamatan periode 3 tahun sebelum dan seluruh periode sesudah BPD DI Yogyaarta, BPD DKI Jakarta dan BPD Jawa Timur menjadi Bank Penyalur KUR terdapat perbedaan yang signifikan. Hasil yang menarik adalah tidak terjadinya perubahan positip yang signifikan NPL sesudah menjadi penyalur KUR. Bahkan meskipun tidak signifikan, Nilai Rerata NPL setelah BPD DI Yogyakarta dan BPD DKI Jakarta menjadi Penyalur KUR memiliki nilai lebih rendah dibanding sebelum menjadi Bank Penyalur KUR, terkecuali BPD DKI Jakarta. Hal ini dapat dimaknai bahwa dengan peningkatan jumlah kredit yang disalurkan BPD masih tetap dapat menjaga kinerjanya dengan mengendalikan NPL di bawah 5 (lima) persen. Pada sisi lain kehadiran KUR belum mampu memberikan kontribusi yang signifikan terhadap pertumbuhan laba BPD. Hal ini diduga karena KUR merupakan kredit program sehingga marginnya kecil dan proporsinya relatif kecil dalam portofolio kredit yang disalurkan oleh BPD (Naasyiatul Lailaa \& Elizabeth Penti Kurniawati, 2018).

\section{KESIMPULAN DAN SARAN}

Hasil pengujian Uji t Berpasangan dan Analisis Jalur dapat disimpulkan bahwa secara keseluruhan (a) variabel Penyaluran Kredit (PK) dan Suku Bunga (SB) terhadap Non Performing Loan (NPL), kedua-duanya secara statistik adalah tidak bermakna, (b) variabel Penyaluran Kredit (PK) dan Suku Bunga (SB) terhadap Biaya Operasional dan Pendapatan Operasional (BOPO), menunjukkan variabel Suku Bunga (SB) secara statistik adalah tidak bermakna dan variabel Penyaluran Kredit (PK) secara statistik adalah tidak bermakna, (c) variabel Non Performing Loan (NPL) dan Biaya Operasional dan Pendapatan Operasional (BOPO) terhadap Return On Asset (ROA), kedua-duanya secara statistik adalah bermakna, (d) variabel NPL pada periode sebelum BPD dan sesudah BPD menjadi penyalur KUR tidak ada perbedaan yang signifikan, sehingga tidak berdampak pada peningkatan kredit bermasalah yang dihadapi oleh pihak BPD, (e) variabel ROA pada periode sebelum BPD dan sesudah BPD menjadi penyalur KUR tidak ada perbedaan yang signifikan, sehingga tidak berdampak pada peningkatan profitabilitas oleh pihak BPD, (f) variabel NIM pada periode sebelum BPD dan sesudah BPD menjadi penyalur KUR tidak ada perbedaan yang signifikan, tidak berdampak kemampuan manajemen bank dalam mengelola aktiva produktifnya untuk menghasilkan pendapatan bunga bersih pada pihak BPD, (g) variabel ROE pada periode sebelum BPD dan sesudah BPD menjadi penyalur KUR terdapat perbedaan yang signifikan, sehingga berdampak pada peningkatan kemampuan menghasilan keuntungan dari modal pihak BPD.

Rekomendasi yang dapat disampaikan bahwa dengan penyaluran kredit dan suku bunga dalam penyaluran KUR secara umum tidak memberikan dampak bermakna terhadap NPL dan BOPO dan variabel kinerja keuangan di tahun-tahun 
BPD menjadi penyalur KUR menunjukkan tidak ada perbedaan signifikan, maka memberikan saran BPD melanjutkan untuk menjadi penyalur KUR. Terdapat keterbatasan-keterbatasan dalam penelitian dalam pengujian kinerja keuangan sebagai dampak penyaluran KUR yang belum memasukan rasio $C A R$ dan $B O P O$ yang perlu menjadi pertimbangan penelitian selanjutnya.

\section{DAFTAR PUSTAKA}

Diana Puspitasari. (2009), Maret 20). Analisis Pengaruh CAR, NPL, PDN, NIM, BOPO, LDR dan Suku Bunga SBI Terhadap ROA (Studi Pada Bank Devisa di Indonesia Periode 2003-2007). Diambil dari http://eprints.undip.ac.id/17071/1/DIANA_PUSPITASARI.pdf

Dwi Prastowo. (2015). Analisis Laporan Keuangan: Konsep dan Aplikasi (Edisi 3). Bandung: UPP STIM YKPN.

Edward W. Reed, \& Edward K. Gill. (1989). Commercial Banking. London: Englewood Cliffts, Nj. : Prentice-Hall.

Eko Aristanto. (2019). Kredit Usaha Rakyat (KUR) : Pilihan Kebijakan Afirmatif Mendorong Pengembangan Usaha Mikro, Kecil dan Menengah di Indonesia. Journal of Banking and Finance, 1 No. 1, 10-23.

Etty M. Nasser. (2003). Perbandingan Kinerja Bank Pemerintah dan Bank Swasta dengan Rasio CAMEL Serta Pengaruhnya Pada Harga Saham. Media Riset Akuntansi, Auditing dan Informasi, 3 No. 3.

Firdaus, \& Dewayanti. (2004). Situasi Tanpa Perlawanan (Penelusuran Kondisi Perempuan Usaha Mikro di Jawa Tengah). Jurnal Perempuan, 35.

I Putu Mulyadi Saputra, Anjuman Zukhri, \& Luh Indrayani. (2014). Sistem Pengendalian Intern Pemberian Kredit Pada PT. BPR Suryajaya Kubutambahan. Jurnal Pendidikan Ekonomi UNDIKSHA, 4 No. 1.

Imam Ghozali. (2007). Manajemen Risiko Perbankan Pendekatan Kuantitatif Value at Risk (VaR) (1st Edition). Semarang: Badan Penerbit Universitas Diponegoro.

Meby Damayanti, \& Latief Adam. (2015, April). Program Kredit Usaha Rakyat (KUR) Sebagai Alat Pendorong Pengembangan UMKM di Indonesia. Diambil dari http://www.tnp2k.go.id/images/uploads/downloads/WP_27_0611-1.pdf

Naasyiatul Lailaa, \& Elizabeth Penti Kurniawati. (2018). Penyaluran Kredit Usaha Rakyat bagi Kinerja Bank Pembangunan Daerah. Jurnal Ekonomi dan Bisnis, 21 No. 1, 24-42.

Sawaldjo Puspopranoto. (2004). Keuangan Perbankan dan Pasar Keuangan. Jakarta: Pustaka LP3ES Indonesia.

Sholikha Oktavi Khalifaturafi'ah, \& Zubaidah Nasution. (2016). Analisis FaktorFaktor Yang Mempengaruhi Kinerja Keuangan Perbankan Di Indonesia. Jurnal Perbankan Syariah, 1 No. 2, 42-63.

Sunarsip. (2011). Relasi Bank Pembangunan Daerah dan Perekonomian Daerah. Pusat Kajian dan Informasi Keuangan Daerah. Diambil dari 
Vol.2, No. 2, Mei. 2019

https://pekikdaerah.wordpress.com/2011/05/13/relasi-bank-pembangunandaerah-dan-perekonomian-daerah/

Timothy W. Koch, \& S. Scott MacDonald. (2009). Bank Management (7 Edition). California: South-Western College Publishing. 